\title{
Nationalist Pluralism in Fiqh Sosial: Ideas and Actions of KH. MA. Sahal Mahfudh
}

\author{
Jamal Ma'mur Asmani*, Arif Chasannudin \\ Institut Pesantren Mathali'ul Falah Pati \\ *Corresponding Author: jamal@ipmafa.ac.id
}

\begin{abstract}
This study explores the ideas and actions of KH. MA Sahal Mahfudh's pluralism as a role model for society. This qualitative descriptive research used fiqh sosial as a tool of analysis. The data is derived from the different works of Kiai Sahal and other supporting works are complemented by interviews with figures who understand the thinking of Kiai Sahal. The results of research on the thoughts and practices of Kiai Sahal on pluralism are fiqh ikhtilaf, the basic principle of pluralism that promotes tolerance, and the state does not need to be labeled Islam. Meanwhile, Kiai Sahal's pluralism practices include accepting Pancasila, fighting for non-Muslim burials, allowing non-Muslims to teach in pesantren, engaging in interfaith cooperation, prohibiting hostility to non-Muslims, and differentiating between religious areas and mu'amalah. Kiai Sahal's contribution to the aspect of thinking is to open up the inclusiveness of thought while in fact, it can enhance the diversity of the country. Based on this research, Kiai Sahal Mahfudh's pluralism style is nationalist pluralism.
\end{abstract}

Keywords: Kiai Sahal, Fiqh Sosial, pluralism, nationalist.

\section{Introduction}

Technological advancement has caused major changes and disturbs everything that has been existed, well set up, and considered sustainable (Gardiner 2017). In this period of disturbance, the building of religious thought that's able to cement the diversity and plurality of the nation is required within the middle of the enormous development of transnational philosophies without reservation in Indonesia. Within the setting of religion, there are Islam, Hinduism, Buddhism, Protestantism, Catholicism, Confucianism, and different other neighborhood convictions and religions (Umar 2019). Religious buildings with a pluralist vision are required to construct agreement amid diversity.

The data released by the Indonesian Survey Institute (LSI) indicates a high degree of intolerance in 2018. The findings of the survey indicate that some Muslim respondents have shown a tendency towards intolerance towards non-Muslims, 
both politically and socially. The total number of respondents in the intolerance group is 52 percent. While the remaining 48 percent fell into the category of tolerance (detikNews 2018).

This radical intolerance ideology has grown in Indonesia due to many factors. First, the textual understanding that opposes the authority of reason on the one hand and on the other hand criticizes the scholars of tafsir and fiqh who open up opportunities for interpretation using other methods, such as language, qiyas, istihsan, maslahah, and others (Kodir 2019). Second, the lack of exemplary role by ulama in active relations with people outside their group and especially across religions is still rare in this country. Third, the role of the state is not so firm that many actions undermine Pancasila and NKRI (the Unitary State of the Republic of Indonesia). Fourth, the expansion of the transnational fundamentalist movement that continues to grow in this country and even penetrates educational institutions (Asmani, 2020). Fifth, weak social control is one of the reasons for the proliferation of intolerant movements that endanger national integration.

Given the above challenges, a comprehensive and inclusive religious construction is required, both on a conceptual and a practical level. One of the scholars who succeeded in doing this task was Kiai Sahal. He was able to produce the concept of fiqh sosial that was accepted by conservative traditional circles and rational modernists. The implementation of fiqh sosial still faces many obstacles, especially from the strong conservatism of the ulama in understanding fiqh with a textual paradigm. Even so, K.H. Sahal Mahfudh continues to make changes in actualizing the theory and practice of fiqh sosial, without having to wait for changes from other scholars (Chasanuddin and Nafisah 2019).

Fiqh sosial paradigm of Kiai Sahal is an interesting study in the context of religious moderation because it includes moderation in the field of thought and social transformation (Asmani, 2017). The fiqh sosial of Kiai Sahal was able to reinforce the growing democracy in Indonesia. Democracy requires rational, emotional, intellectual, and social maturity so that it can coexist with other religions and groups. Democracy also encourages active cross-sectoral cooperation to jointly build the nation from various aspects of life. Kiai Sahal's life practice is an example of moderation and coexistence. 
This study is qualitative research with a descriptive approach to explaining the thoughts and actions of Kiai Sahal's pluralism. Data collection techniques used in this research are document study, observation, and interviews with people who are connected to and knowledgeable of Kiai Sahal's thoughts on pluralism. The qualitative analysis approach in this study is comparative, i.e. the analysis is carried out by comparing one data to another. Fiqh sosial is used as the key theoretical basis and analytical tool in the evaluation of research results, so that it can be understood if Kiai Sahal's ideas and practices in the sense of pluralism meet the characteristics of fiqh sosial.

\section{Fiqh Sosial Doctrine Kiai Sahal's on Religious Pluralism}

Religious pluralism, according to Nurcholis Madjid, underlines the notion that all religions have the right to live at the expense of each religious follower, either individually or in groups (Madjid 2000). Religious pluralism is not only a sociological recognition that religious people are different, but also an acknowledgment of theological meeting points between religious communities. When religion is understood by humans, then the truth of religion cannot be fully reached by humans, because humans are relative. Religious truth is relative, not absolute. Absolute truth is a religious truth known to the knowledge of God (Hanik 2014).

Religious pluralism is one of the most interesting issues to study with fiqh sosial. Fiqh Sosial encourages actualized fiqh concepts in people's lives so that people avoid secularism which keeps people away from fiqh as the real manifestation of religion in everyday life. Fiqh Sosial has five characteristics, namely the contextual understanding of fiqh texts, changes in madzhab trends from qauli to manhaji, basic verification between ushul and furu' teachings, rendering fiqh as a social ethic a non-positive state law, and introducing philosophic thought, particularly on social issues (Asmani, 2015).

The operational of the Fiqh Sosial concept is carried out by developing qauli and developing manhaji. The development of fiqh by qauli is carried out by contextualizing the yellow book by developing examples of applications of the principles of fiqh andqawā'id al-fiqhyiyah. Meanwhile, manhaji development can be 
done by developing theorymasālik al-'illat (Judges 2019). Fiqh Sosial rests on the principle of 'al-muhafadzah ala al-qadim al-shalih wa al-akhdzu bi al-jadid al-ashlah' (keeping good old traditions and taking new traditions better). Both must be placed in a balanced manner to maintain the elasticity of fiqh and its suitability at all times (Baroroh 2020).

The study of Fiqh Sosial on religious pluralism gave birth to the concept of fiqh ikhtilaf (fiqh difference), namely ethics, insights, and solutions to neutralize information between Islamic groups that threaten the unity and integrity of Muslims. There are several ethics of ikhtilaf, including husnudzdzan (kind thought) to fellow Muslims, respecting people's opinions as long as there are arguments, avoiding coercion of the will that their opinion is the most correct because there is a possibility that other opinions are right, responding to differences openly and seeing them as positive things that enrich religious treasures. Also, they do not tend to blame and accuse unknown teachings of being heretical because they must first be studied the background and doctrine of their teachings (Kiai Sahal, 2003).

Fiqh ikhtilaf in addressing religious pluralism in diverse societies can answer the question of why the ulama have high nationalism. Nationalism is a notion that is manifested in a movement that yearns for collective interests, namely the interests of the nation, even though it consists of a pluralistic society. In nationalism, the substantial element is a willingness to unite (a living and active corporate will) (Moesa 2007). Ulama nationalism is the agreement of traditional leaders to maintain and solidify Indonesian nationalism without distinguishing the interests of religion, people, ethnicity, class, and even their interests. They have a commitment to strengthening nationalism in any difficult situation, including when the nation is faced with the rampant movement back to ethnicity, group primordialism, and even religious fundamentalism.

The nationalism of the ulama is also seen in the thought of K.H. Ahmad Shiddiq's ukhuwwah trilogy, namely ukhuwwah basyariyyah, ukhuwwah Islamiyah, and ukhuwwah wathaniyah, which serve as guides in associating with others regardless of differences in religion, ethnicity, race, and language. The Kiai prioritize the transformation of Islamic values in the life of the nation and state (Moesa 2007). 


\section{Pluralism, Tolerance, and Democracy}

The basic concept of pluralism according to Kiai Sahal is the ability to understand and appreciate diversity (Mahfudh, 2003). This is confirmed in The Quran Surah Al-Hujurat 13:

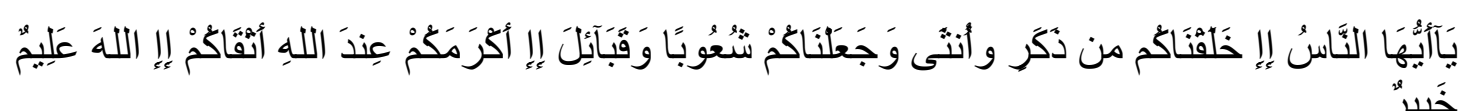

o people, indeed We created you from a man and a woman and made you nations and tribes so that you would know each other. Surely the noblest among you in the sight of Allah is the most pious of the people. You, Allah, is AllKnowing, All-Knowing (The Quran. 49:13).

The principle put forward in interactions with fellow Muslim Kiai Sahal is ukhuwwah Islamiyyah (brotherhood between fellow Muslims), while interaction with non-Muslims is the principle of tolerance for the benefit of the general public. Understanding each other will give birth to social discipline (Mahfudh 2012). One of the drivers of the urgency of tolerance is the pluralistic reality of the nation which requires mutual respect between various groups (Mahfudh 2012).

Ukhuwwah is invisible in social reality. This can be caused by ignorance, the pettiness of thinking, blind fanaticism, excessive pride in one's group, lack of friendship and open dialogue, decreased awareness of good morals, and lack of exemplary (Mahfudh 2012). Sectarianism is an attitude that should be avoided because it confuses tolerance and respect. The domination of the great power that oppresses the small group must be eliminated. Therefore, common interests must be prioritized over sectarian interests (Mahfudh 2012). Kiai Sahal prioritizes collective interests rather than group interests.

All scholars agree that a leader absolutely must have the character, attitude, behavior and policies that are just towards the people. The arguments used are not only naqliyah and 'aqliyah, but also 'adiyah/thabi'iyah arguments. Therefore, justice, especially for leaders, is a social norm that is needed in the life of society, nation, and state by any nation. If a leader is unfair, then the negative impact is wider than what is done by someone who does not have a position. No one likes injustice, accepts injustice, and approves of abuse (Mahfudh 2012).

Meanwhile, concerning democracy, it requires Muslims to have an insight into Islam and politics as a prerequisite for creating a consensus-based on pluralistic 
awareness. The consensus is Bhinneka Tunggal Ika. This awareness will create tolerance and mutual respect between various groups. Tolerance and mutual respect between groups are prerequisites for democracy. Democracy encourages the full participation of people without threats and coercion. This is largely determined by the awareness of the rights and obligations of the nation and state (Mahfudh 2012).

\section{Pluralism Practices of Fiqh Sosial's Kiai Sahal}

Kiai Sahal is one of the NU exponents who accepted Pancasila as the basis of organization in the 27th NU Congress in Situbondo in 1984. According to KH. Husein Muhammad, Kiai Sahal's theological basis and theory of humanity are strong. The togetherness of Kiai Sahal with the others and his approval of the 1984 NU Congress decision regarding Pancasila and the nation-state is sufficient evidence to affirm virtue and strengthen interfaith relations (Muhammad 2020). Therefore, there is no need to hate non-Muslims. Ukhuwwah wathaniyyah (homeland brotherhood) and ukhuwwah basyariah (human brotherhood) are the basis for thinking and behaving apart from ukhuwwah Islamiyyah (brotherhood of fellow Muslims) (Umam 2020).

Kiai Sahal's conviction that the Indonesian state is based on Pancasila is final in recognizing that diversity is a requirement for all people to be covered (Achmad 2020). He was involved in the formulation of the NU khittah at the 27th Congress in Situbondo in 1984 which covered all aspects including the fields of faith, syari'ah, morals-tasawuf, mu'asyarah which used the principles of mutual understanding, state life, preaching, and culture (Shiddiq 2005).

In practice, the Kiai Sahal community shows high respect for humanity. At that time in Margoyoso there was a polemic about non-Muslim burials which many people rejected. In this case, Kiai Sahal stated, if Muslims reject Christian burials, then Muslims must be willing to buy land for non-Muslim burials and Kiai Sahal is willing to participate in buying them. This is inseparable from Kiai Sahal's consideration that the deceased must be buried or burned in a certain religion, otherwise it will become a disease (Muhtarom 2020).

In the field of education, Kiai Sahal is a drafter of education as well as an inclusive educator. The inclusiveness of Kiai Sahal's educational thinking was seen when he allowed a non-Muslim foreigner named Paul Musante from America to 
teach English at the Pesantren Maslakul Huda (Sutaman 2020). This foreigner has lived in the Pesantren for two years and is active in community empowerment. Kiai Sahal's decision took place around 1982-1983 (Umam 2020) and the community responded differently, some groups thought that Kiai Sahal was influenced by nonMuslims. This is very reasonable because it is not uncommon for non-Muslims to live and teach in Pesantren.

Economic problems have become an area of serious concern for the thoughts and practices of fiqh sosial Kiai Sahal's. He is directly involved in the community economic empowerment program with the BPPM (Pesantren and Community Development Bureau) Pesantren Maslakul Huda. This program collaborates with the Non-Governmental Organization (NGO) Novib and several Western NGOs. In undergoing this program, Kiai Sahal was protested by the Nahdlatul Ulama (NU) Kiai because of the problem of receiving Western foreign assistance for the pesantren and community development program. Kiai Sahal responded to this protest by gathering Kiai and there was an interesting dialogue between Kiai Sahal and the Kiai so that the program ran smoothly.

Kiai Sahal, when he served as the Chancellor of UNISNU, was involved in cooperation related to campus programs with government programs such as family planning, community B3B alleviation (free three blinds), and others (As-Saidi 2020). Kiai Sahal often attends seminar related to community development and Pesantrens, whether organized by Muslims or not. Kiai Sahal has gone abroad several times at the invitation of the government or other parties who are nonMuslim (Umam 2020). Among Kiai Sahal's overseas travel experiences are a comparative study of community development to the Philippines in 1983 with USAID sponsorship, a comparative study of community development to South Korea in 1983 under USAID sponsorship, a comparative study of community development to Sri Lanka in 1984, and visits to Malaysia and Thailand for the benefit of the National Education Advisory Board (IBRA) in 1997 (Mahfudh, 2003).

So it is not surprising that Kiai Sahal has many colleagues and friends from various backgrounds and various religious backgrounds. Among his close nonMuslim colleagues are Sudamek, the owner of the Kacang Garuda Group, Jacobus Busono, the leader of Pura Kudus Group, and many more (Rofi'an Ahmad 2020). The 
friendship made by him was in the context of bringing together ukhuwah basyariayah and mutually beneficial cooperation between the two parties. He also received guests from groups of orientalist professors (Sutaman 2020).

The depth and breadth of Kiai Sahal's knowledge and insight are not only about religion but also in the context of national insight. Kiai Sahal used to give brief directions that were usually delivered in joint meetings of Syuriah and Tanfidziyah PBNU (Ahmad, 2020). He forbade Muslims to be hostile to non-Muslims (Wakhrodi 2020). In the context of respecting this plurality, Kiai Sahal distinguishes between areas of worship and mu'amalah. Kiai Sahal has attended non-Muslim events that are not religious rituals, but it seems that they never seem to be religious rituals of other religions" (Janah 2020). This statement affirms tolerance in the context of $m u$ 'amalah, but the problem of worship is the problem of each religious adherent according to their beliefs.

Kiai Sahal actively collaborates with many groups across sectors (Abdalla 2020). He did not answer the problem asked by the group of East Javanese scholars about the Shia issue, preferring to remain silent. After the meeting, the scholars were disappointed because the fatwa of Kiai Sahal that had been waiting for was not issued. Kiai Sahal did not recklessly give fatwas because he considered the benefit and harm of the fatwa. This cannot be differentiated from the law of fiqh that the general benefit must take precedence over the particular advantage.

\section{Contribution of Fiqh Sosial in Strengthening Religious Pluralism in Indonesia}

In the aspect of thinking, Kiai Sahal made religious thought inclusive. According to Syafii Anwar, the typology of substantive-inclusive political thinking, is characterized by the belief that the Koran includes ethical dimensions and moral standards of life, believes that the Prophet's main mission is to preach Islamic ideals and virtues, believes that the Shari'a is not limited or bound by the state, and emphasizes the significant manifestation of Islamic importance in political activism (Anwar 2006). The inclusiveness of Kiai Sahal's thought is inseparable from his openness to access various references as long as it brings progress and avoids backwardness. One of the principles is "khuz maa shafaa wada' maa kadar", take the clean ones, and leave the dirty ones. This is the specialty of Kiai Sahal; he can create 
a middle way between orthodoxy and liberalism. The thoughts expressed by Kiai Sahal are still focused on classical texts and are important to the problems of the modern world, but they do not disappear in boundless modernity.

The second contribution, in practical terms, is to improve the diversity of the country in internal and external dimensions. Internally, Kiai Sahal's thought contributions include the pesantren, Nahdlatul Ulama, and Muslims. An remarkable reality is the product of the National Conference in Banjar, West Java (2019), which does not call non-Muslims non-Muslims, but citizens of equal status with fellow citizens of other countries. Kiai Sahal prefers a silent strategy when asked for a fatwa on Syi'ah because brotherhood between fellow Muslims and fellow citizens must be maintained and do not open up gaps in the tyranny of the majority.

Externally, relations with other religions are harmonious. His position as PBNU Rais 'Am Syuriyah and Chairman of the Indonesian Ulama Council (MUI) can protect non-Muslims while maintaining Islamic ethics that protect and respect nonMuslims. It also prevents words or acts that cause tension and confrontation that are counter-productive to attempts to achieve national unity and integrity.

The ideas and practices of Kiai Sahal in the sense of preserving diversity, as in the previous analysis, turned out to be based on the doctrine of fiqh sosial. This means that the da'wah bil hal (behavior) displayed by Kiai Sahal is following the da'wah bil maqal (fiqh sosial paradigm) which was initiated and fought for by Kiai Sahal in achieving the benefit of the people. The harmony between thought and action, followed by a thorough understanding of religious teaching, has made Kiai Sahal a charismatic and wise figure.

That is, the da'wah bil hal displayed by Kiai Sahal is in accordance with the da'wah bil maqal (Fiqh Sosial paradigm) initiated and championed by Kiai Sahal in dynamizing the paradigm of the people. 
Globally it can be seen in the table below:

Table 1.

Pluralism in Fiqh Sosial

\begin{tabular}{|c|c|c|c|c|}
\hline NO & DOCTRINE & PRACTICE & CONTRIBUTION & $\begin{array}{l}\text { ANALYSIS OF SOCIAL } \\
\text { SCIENCE } \\
\end{array}$ \\
\hline 1 & Ikhtilaf Fiqh & Accept Pancasila & \multirow{11}{*}{$\begin{array}{l}\text { First, thought. } \\
\text { In the aspect of } \\
\text { thinking, KH. MA. } \\
\text { Sahal Mahfudh } \\
\text { makes religious } \\
\text { thought inclusive }\end{array}$} & $\begin{array}{l}\text { Manhaji school and } \\
\text { verification of ushul and furu ' }\end{array}$ \\
\hline 2 & $\begin{array}{l}\text { Basic Principles of } \\
\text { Pluralism }\end{array}$ & $\begin{array}{lr}\text { Khittah } & \text { Nahdliyyah } \\
\text { Fighting } & \text { For } \\
\text { Undeveloped NKRI }\end{array}$ & & $\begin{array}{l}\text { Contextualize the text of fiqh } \\
\text { and make fiqh a social ethic }\end{array}$ \\
\hline 3 & $\begin{array}{l}\text { Promoting } \\
\text { Tolerance }\end{array}$ & $\begin{array}{l}\text { Non-Muslim } \\
\text { Cemeteries }\end{array}$ & & $\begin{array}{l}\text { 'Illat hokum and wisdom of } \\
\text { law in the framework of } \\
\text { maqasidus syari'ah }\end{array}$ \\
\hline 4 & $\begin{array}{l}\text { The state does not } \\
\text { need to be labeled } \\
\text { as Islamic }\end{array}$ & $\begin{array}{l}\text { Non-Muslim } \\
\text { foreigners teach at } \\
\text { Pesantren }\end{array}$ & & $\begin{array}{l}\text { The contextualization of the } \\
\text { text of fiqh and making fiqh as } \\
\text { social ethics, is not positive } \\
\text { law of the State }\end{array}$ \\
\hline 5 & Demokrasi & $\begin{array}{lr}\text { Kerjasama } & \text { program } \\
\text { Budidaya Kambing } \\
\text { dan Bebek dengan } \\
\text { LSM Novib dan } \\
\text { beberapa LSM Barat }\end{array}$ & & $\begin{array}{l}\text { Ushul and furu' verification } \\
\text { and introducing philosophical } \\
\text { thinking, especially in socio- } \\
\text { cultural issues }\end{array}$ \\
\hline 6 & & $\begin{array}{l}\text { Interfaith } \\
\text { Cooperation }\end{array}$ & & Making fiqh social as a ethic \\
\hline 7 & & $\begin{array}{l}\text { Good friends with } \\
\text { non-Muslim Chinese }\end{array}$ & & $\begin{array}{ll}\text { Jurisprudence } & \text { text } \\
\text { contextualization } & \\
\end{array}$ \\
\hline 8 & & $\begin{array}{l}\text { Forbid being hostile to } \\
\text { Non-Muslims }\end{array}$ & & $\begin{array}{l}\text { Illat Hukum and the wisdom } \\
\text { of law with the orientation of } \\
\text { maqasid sharia }\end{array}$ \\
\hline 9 & & $\begin{array}{lr}\text { Distinguishing } & \text { Areas } \\
\text { of Worship } & \text { and } \\
\text { Muamalah } & \\
\end{array}$ & & Ushul and furu' verification \\
\hline 10 & & $\begin{array}{l}\text { Raising Ukhuwah with } \\
\text { Muhammadiyah }\end{array}$ & & Ushul and furu' verification \\
\hline 11 & & $\begin{array}{l}\text { Prefer silence in order } \\
\text { to guard against } \\
\text { greater damage }\end{array}$ & & Madzhab qauli and manhaji \\
\hline
\end{tabular}

\section{Finding: Nationalist pluralism}

Based on the above analysis, it has been found that the model of pluralism closest to Kiai Sahal is nationalist pluralism. Nationalist pluralism was born out of great love and commitment to the country and was aimed at strengthening social unity. The public interests of the country have priority over individual and primary interests. The goal of Kiai Sahal's pluralism is to create the solidarity, unity, and dignity of religious communities so that this nation is not stuck in conflict, agitation, and social confrontations that undermine society. Therefore, the most prominent feature of Kiai Sahal's pluralism is nationalist pluralism. 
Kiai Sahal's nationalist pluralism has been founded on solid religious and social foundations. This is because Kiai Sahal's pluralism is based on a deep comprehension of the Koran, Hadith, the views of scholars, and Kiai Sahal's ijtihad. The pluralism championed by Kiai Sahal is also intended to improve the relationship between fellow people and fellow human beings in their lives and lives. Kiai Sahal's contribution to this nationalist pluralism is not only verbal but also demonstrated in reality. The pesantren he leads are used as a model for the growth of society in all fields.

\section{Conclusion}

In inclusive religious thought, the contribution of KH. MA. Sahal Mahfudh to fiqh sosial in enhancing religious pluralism in Indonesia seems so accepting of differences. This thought is then manifested in concrete actions to protect and respect people of other religions in social relations. Based on this research, it could be said that nationalist pluralism is the style of the pluralism of Kiai Sahal because it was born on a detailed understanding of religion and a great love for the country and state. As good fellow citizens, it is a must to aid in kindness so that there is a common shared awareness that enhances and complements togetherness, a sense of belonging.

\section{References}

Abdalla, U. A. (2020). Interview.

Achmad, N. (2020). Interview.

Anwar, M. S. (2006). Islamku, Islam Anda, Islam Kita, Membingkai Potret

Pemikiran Politik KH. Abdurrahman Wahid. In Islamku, Islam Anda, Islam Kita (pp. xvii-xviii). The Wahid Institute.

As-Saidi, S. (2020). Interview.

Asmani, J. M. (2015). Mengembangkan Fikih Sosial KH. MA. Sahal Mahfudh, Elaborasi Lima Prinsip Utama. Quanta Gramedia.

Asmani, J. M. (2017). Rekonstruksi Teologi Radikalisme di Indonesia, Menuju Islam Rahmatan Lil Alamin. Wahana Akademika: Jurnal Studi Islam Dan Sosial. https://doi.org/10.21580/wa.v4i1.1475

Asmani, J. M. (2020). Al-Qur'an Berjalan: Meneladani Nabi Muhammad, Ulama, Dan 
Santri. Aswaja Pressindo.

Baroroh, U. (2020). Understanding Methodology of Fiqh Sosial. Santri: Journal of Pesantren and Fiqh Sosial, 1(1).

Chasanuddin, A., \& Nafisah, Z. (2019). Konsep Mashlahah al-Ammah dalam Perspektif Fiqh Sosial KH. MA. Sahal Mahfudh. Islamic Review : Jurnal Riset Dan Kajian Keislaman, 8(2), 235-258. https://doi.org/10.35878/islamicreview.v8i2.177

Hakim, M. L. (2019). Aplikasi Konsep Fiqh Sosial KH. M.S. Sahal Mahfudh terhadap Batas Usia Perkawinan dalam Pasal 7 ayat (1) Undang-Undang Perkawinan No.2 Tahun 2019. Islamic Review: Jurnal Riset Dan Kajian Keislaman, VIII(2), 210. https://doi.org/10.35878/islamicreview.v8i2.174

Hanik, U. (2014). Pluralisme Agama Di Indonesia. Jurnal Pemikiran Keislaman, 25(1), 44-63. https://doi.org/10.33367/tribakti.v25i1.154

Ishomuddin Ahmad. (2020). Interview.

Janah, T. N. (2020). Interview.

Kodir, A. F. (2019). Qira'ah Mubadalah, Tafsir Progresif untuk Keadilan Gender dalam Islam.

Madjid, N. (2000). , Islam Doktrin dan Peradaban,. Paramadina.

Mahfudh, M. S. (2012). Nuansa Fiqh Sosial. Penerbit LKiS.

Mahfudh, S. (2003). Fiqh Sosial Upaya Pengembangan Madzhab Qauli dan Manhaji. UIN Syarif Hidayatullah.

Moesa, A. M. (2007). Nasionalisme Kiai. LKiS.

Muhammad, K. H. (2020). Interview.

Muhtarom, A. (2020). Interview.

Rofi'an Ahmad. (2020). Interview.

Shiddiq, A. (2005). Khittah Nahdliyyah (3rd ed.). Khalista dan LTN NU.

Sutaman, N. (2020). Interview.

Umam, S. (2020). Interview.

Wakhrodi. (2020). Interview. 